\title{
Effects of fermentation on the proximate, anti-nutrients, minerals, fatty acids, and amino acids profiles of jujube (Ziziphus mauritiana Lam) seeds
}

\author{
Rhamatallah Adenike Alawode ${ }^{1 *}$, Muhammed Muhammed Ndamitso ${ }^{2}$ \\ Yahaya Ahmed Iyaka² and Julian Chukwuemeka Anuonye ${ }^{3}$
}

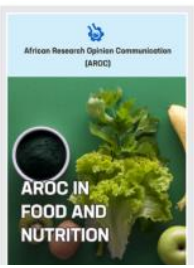

Department of ${ }^{1}$ Forestry Research Institute of Nigeria-Southern Guinea Research Station, Mokwa, Niger State, Nigeria 2Department of Chemistry, Federal University of Technology, Minna, P.M.B. 65, Niger State, Nigeria

${ }^{3}$ Department of Food Science and Technology, Federal University of Technology, Minna, P.M.B. 65, Niger State, Nigeria.

*Correspondence:

Rhamatallah Adenike Alawode

Email: rahmatallahadenike@gmail.com

Received: 03 March 2021, Revised: 19 August 2021, Published: 03 September 2021

\section{ABSTRACT}

Background: Fermentation has been recognized as one of the oldest ways of food processing that increase food quality by increasing nutrient bio-availability through the reduction in anti-nutrient compositions. The present study evaluated the effects of fermentation on nutrients and anti-nutrients composition of jujube (Ziziphus mauritiana Lam) seed. Methods: The seed of $Z$. mauritiana was fermented for $24 \mathrm{hr}$. Standard analytical procedures were used to analyse the proximate, minerals, amino acid, fatty acid and anti-nutrient compositions of the seed sample at $0,6,12,18$ and $24 \mathrm{hr}$ of fermentation. Results: The seed has high amounts of proteins, minerals, amino acids and low levels of anti-nutrients. The seed also has higher unsaturated than saturated fatty acids. Fermentation significantly increased the minerals compositions, decreases anti-nutrients and some amino acid levels but had no plausible effects $(p>0.05)$ on proximate contents of the seed. Fermentation for 6 and 12 hr had no significant $(p<0.05)$ effect on the fatty acids, however, at 18 and 24 hr a significant $(p<0.05)$ reduction in fatty acid were recorded. On the basis of nutrient retention, the most plausible and positive effects of the fermentation on Z. mauritiana were observed at $\leq 12$ of fermentation. Conclusion: Ziziphus mauritiana seed could be employed as an alternative source of nutrients for humans and animals. However, fermentation of $Z$. mauritiana should be done for a period of $\leq 12 \mathrm{hr}$ if necessary.

Keywords: Ziziphus mauritiana; fermentation; proximate; fatty acid; anti-nutrients; minerals; amino acid Citation: Alawode, A.R., Ndamitso, M.M., Iyaka, A.Y., and Anuonye, C.J., (2021). Effects of fermentation on the proximate, antinutrients, minerals, fatty acids, and amino acids profiles of jujube (Ziziphus mauritiana Lam) seeds. AROC in Food and Nutrition, 1(1), 31-40, https://doi.org/10.53858/arocfn01013140

\subsection{Introduction}

In spite of the exigent effort to meet the nutritional requirements of the everincreasing populations, many cheap sources of protein are available but not generally acceptable to the consumers due to undesirable characteristics, presence of antinutritive factors and lack of knowledge on their nutritional qualities and thus remain relatively under-utilized [1].

Research interest geared towards unravelling the chemical composition of some wild fruits in developing countries like Nigeria is increasing rapidly, owing to their significant roles in the diet of people of the developing world [2]. These wild fruits may offer better or comparable nutritional and phytoconstituents than the cultivated fruits [3]. However, the anti-nutritional contents of some of these fruits may interfere with the metabolic process and thus limit nutrient bioavailability by the body when consumed [4]. Fermentation has been recognized as one of the oldest ways of food processing that increase food quality by increasing nutrient bio-availability through the reduction in antinutrient compositions [5]. Thus, fermented foods constitute an important part of the diet in many communities in the world. The functional microorganisms in food fermentations include bacteria, yeasts and moulds.

Ziziphus mauritiana Lam. belongs to the Rhamnaceae family it is an important tropical fruit tree commonly known as Jujube or Magarya by English and Hausa speaking of northern Nigeria [6]. The tree is native to tropical Africa and grows in arid and semiarid regions [7]. $Z$. mauritiana have been reportedly used in traditional medicine for the treatment of sexual disability, cough, digestive disorders, urinary troubles, loss of appetite, convulsion, epilepsy, insomnia 
obesity, burning sensations, fever, skin disease, wound, ulcers, diarrhoea and stomatitis [8]. Pharmacologically, $z$. mauritiana has been reported to contain bioactive metabolites including flavonoids, glycosides, saponins and volatile oil [9], with different pharmacological effects; immune stimulation [10], activities against alcoholinduced oxidative stress [11], anticancer [12], antidiarrhoeal [9], hypoglycemic and hypolipidemic [13], antiulcer [14], and antimicrobial [15] activities.

The fruit of $Z$. mauritiana enclosed a single or two seeds which are often discarded as waste. Seeds are dispersed by human and other mammalian vectors [16]. Despite the wellknown medicinal properties of $Z$. mauritiana, the seed is less explored and underutilized and could serve as a rich source of nutrients and phytochemicals for the general benefits of the population [17].

To date, there had not been detailed scientific documentation on the chemical (nutritional, and antinutritional) composition of $Z$. mauritiana seeds. The available literature is limited to only its proximate compositions [17]. Therefore, it becomes relevant to investigate the chemical composition of $Z$. mauritiana seed and also the effect of fermentation on these compositions. This would go a long way to supplement the nutrients needs and demands of humans and animals in Nigeria and Africa at large.

\subsection{Materials and Methods}

\section{1 Sample collections}

Matured fruits of $Z$. mauritiana fruits were picked directly from the trees in March 2017 from the Barnawa area of Kaduna, Kaduna State. The sample was identified and authenticated at the herbarium unit of the Department of Biological Sciences Ahmadu Bello University where the existing voucher number of the specimen (No. 7072) was given

\subsection{Sample preparation and fermentation}

The fruits were macerated in water to remove the pulp and the seeds were rinsed in clean water. Thereafter the seeds were spread out, sun-dried. The dried seeds were grounded and sieved through a mesh to obtain a fine powder which was stored in an airtight container. The powdered seed $(100 \mathrm{~g})$ was fermented with $500 \mathrm{~cm} 3$ of distilled water with the aid of yeast (saccharomyces), samples were taken out of the fermentation medium at $6 \mathrm{hr}^{\prime}$ intervals (0, $6,12,18$ and $24 \mathrm{hr}$ ) for analysis of chemical composition. After each fermentation period, the substrates were dried at $50^{\circ} \mathrm{C}$ in the oven and kept refrigerated pending analysis

\subsection{Mineral Analysis}

The concentration of sodium, potassium, calcium, magnesium, copper, manganese, iron zinc and phosphorus in $Z$. mauritiana seeds were analysed according to AOAC [18]. Ten $(10 \mathrm{~g})$ grams of each of the samples was heated over a flame and ashed in muffle furnace at $450^{\circ} \mathrm{C}$ for $8 \mathrm{hr}$. Ten $\left(10 \mathrm{~cm}^{3}\right)$ of diluted $\mathrm{HCl}$ was added to the ash and boiled for 5 minutes. The boiled ash was made up to $100 \mathrm{~cm}^{3}$ with distilled water. Analysis were performed in triplicate using atomic absorption spectrophotometer according to the standard methods of AOAC [18].

\subsection{Proximate analysis:}

The proximate indices of $Z$. mauritiana seeds including; crude proteins, crude fibre, moisture content, ash content, crude fat and carbohydrate were determined using standard procedures [18].

\subsection{Anti-nutritional analysis}

Tannin content was determined by the method of Makkaret al. [19]. Phytate was determined using the procedure of Oboh [20]. Oxalates were determined by the standard method [18]. Saponins were quantified by the method of Doss et al. [21] while Alkaline Titration Method [18] was used for hydrogen cyanide

\subsection{Amino acids (AA) analysis}

Ten $(10 \mu \mathrm{L})$ of defatted seed samples were analyzed for the amino acid profile using Amino Acid Analyser (TSM), (Technicon Instruments Corporation, New York). The analysis period was $76 \mathrm{~min}$ with a column flow rate of $0.50 \mathrm{~cm} 3 / \mathrm{min}$ at $600 \mathrm{C}$ with reproducibility consistent within $\pm 3 \%$. The net height of each peak produced by the chart record of TSM was measured and calculated for the amino acid it represented.

\subsection{Fatty acid analysis}

Fatty acid methyl esters (FAMEs) FAMEs were prepared using the methods reported by Yurchenko et al. [22] with slight modification. 
FAME standards were used for both qualitative and quantitative analysis of the fatty acid composition of seed oil. Standards used for this analysis were caprylic acid (C8:0), capric acid (C10:0), lauric acid (C12:0), myristic acid (C14:0), palmitic acid (C16:0), palmitoleic acid (C16:1), stearic acid (C18:0), oleic acid (C18:1), linoleic acid (C18:2), arachidic acid $(\mathrm{C} 20: 0)$, linolenic acid (C18:3), behenic acid (C22:0), erucic acid (C22:1), and lignoceric acid (C24:0). For quantitative analysis, 6 concentrations $(1,10,20,40,60$, and 100 $\mathrm{mg} / \mathrm{mL}$ ) of the mixed standards were analyzed, to allow construction of a standard curve of each fatty acid. All data were acquired using the Agilent ChemStation software.

\subsection{Statistical Analysis}

Data were analyzed using Statistical Analysis System (SAS) and presented as means \pm SD. Comparisons between different groups were carried out by one-way analysis of variance (ANOVA) followed by Duncan's Multiple Range Test (DMRT). The level of significance was set at $P<0.05$

\subsection{Results}

\subsection{Effect of fermentation on fatty acid profiles of $Z$. mauritiana seeds}

The Unsaturated and saturated fatty acid compositions of $Z$. mauritiana seeds are presented in Tables 1 . Unsaturated fatty acids including palmitoleic, oleic, erucic, linoleic and linolenic acid of $Z$. mauritiana seeds oil were not significantly $(p>0.05)$ altered by fermentation for 6 and $12 \mathrm{hr}$. However, at 18 and $24 \mathrm{hr}$ of fermentation a significant $(p<0.05)$ reduction in these fatty acids were recorded. The decrease in nutrients was more pronounced $(\mathrm{p}<0.05)$ at $18 \mathrm{hr}$ of fermentation than at $24 \mathrm{hr}$ (Table 1 ).

Saturated fatty acids including caproic, caprylic, capric lignoceric, and margaric acid significantly $(p<0.05)$ decreases with all fermentation periods tested. Lauric, myristic, palmitic, stearic, arachidonic and behenic acid concentrations in seed fermented for 6 and 12 hr were not significantly $(p>0.05)$ different from the unfermented seed samples. These fatty acid concentrations were significantly $(p<0.05)$ lowered in seed fermented for 18 and $24 \mathrm{hr}$ (Table 2)

Table 1: Effect of fermentation on the un saturated fatty acid compositions of Ziziphus mauritiana Seeds

\begin{tabular}{|c|c|c|c|c|c|}
\hline Fatty Acids & Fmt_0 hr & Fmt_6 hr & Fmt_12 hr & Fmt_18 hr & Fmt_24 hr \\
\hline Palmitoleic (C16:1) & $0.06 \pm 0.01^{\mathrm{b}}$ & $0.07 \pm 0.01^{\mathrm{b}}$ & $0.09 \pm 0.01^{\mathrm{b}}$ & $0.01 \pm 0.01^{\mathrm{a}}$ & $0.02 \pm 0.01^{\mathrm{a}}$ \\
\hline Oleic (C18:1) & $14.01 \pm 0.06^{\mathrm{b}}$ & $14.11 \pm 0.02^{\mathrm{b}}$ & $14.15 \pm 0.02^{\mathrm{b}}$ & $9.71 \pm 0.02^{\mathrm{a}}$ & $12.80 \pm 0.03^{\mathrm{ab}}$ \\
\hline Erucic (C22:1) & $0.19 \pm 0.03^{\mathrm{c}}$ & $0.22 \pm 0.04^{\mathrm{c}}$ & $0.26 \pm 0.02^{\mathrm{c}}$ & $0.05 \pm 0.01^{\mathrm{a}}$ & $0.11 \pm 0.02^{\mathrm{b}}$ \\
\hline Linoleic (C18:2) & $48.71 \pm 0.02^{\mathrm{b}}$ & $48.73 \pm 0.01^{\mathrm{b}}$ & $48.76 \pm 0.02^{\mathrm{b}}$ & $34.52 \pm 0.01^{\mathrm{a}}$ & $43.81 \pm 0.04^{\mathrm{b}}$ \\
\hline Linolenic (C18:5) & $0.56 \pm 0.02^{\mathrm{c}}$ & $0.59 \pm 0.01 \mathrm{C}$ & $0.62 \pm 0.01^{\mathrm{c}}$ & $0.26 \pm 0.01^{\mathrm{a}}$ & $0.34 \pm 0.03^{\mathrm{b}}$ \\
\hline O/L ratio & $1 / 3.47$ & $1 / 3.45$ & $1 / 3.44$ & $1 / 3.55$ & $1 / 3.42$ \\
\hline
\end{tabular}

Values are mean \pm SD of 3 determinations. Values with different superscript alphabet along a column are significantly different at $\mathrm{p}<0.05$ : Fmt_0 hr= unfermented sample; Fmt_6 hr= fermented for $6 \mathrm{hr}$; Fmt_12 hr= fermented for $12 \mathrm{hr}$; Fmt_18 hr= fermented for $18 \mathrm{hr}$; Fmt_ $24 \mathrm{hr}=$ fermented for $24 \mathrm{hr}$.

\begin{tabular}{|c|c|c|c|c|c|c|}
\hline Caprylic & $\mathrm{C} 8: 0$ & $0.12 \pm 0.01^{\mathrm{e}}$ & $0.10 \pm 0.01^{d}$ & $0.07 \pm 0.03^{c}$ & $0.01 \pm 0.00^{a}$ & $0.05 \pm 0.03^{b}$ \\
\hline Lauric & C12:0 & $1.76 \pm 0.01^{b}$ & $1.71 \pm 0.04^{b}$ & $1.62 \pm 0.01^{b}$ & $1.12 \pm 0.01^{a}$ & $1.23 \pm 0.03^{a}$ \\
\hline Myristic & $\mathrm{C} 14: 0$ & $1.24 \pm 0.02^{c}$ & $1.20 \pm 0.02^{c}$ & $1.13 \pm 0.02^{b c}$ & $0.58 \pm 0.01^{a}$ & $1.00 \pm 0.04^{b}$ \\
\hline Margaric & C17:O & $0.17 \pm 0.02^{c}$ & $0.12 \pm 0.01^{b}$ & $0.10 \pm 0.01^{b}$ & $0.07 \pm 0.01^{a}$ & $0.06 \pm 0.01^{a}$ \\
\hline Stearic & C18:0 & $11.81 \pm 0.03^{b}$ & $11.85 \pm 0.05^{b}$ & $11.91 \pm 0.02^{b}$ & $9.03 \pm 0.01^{a}$ & $10.36 \pm 0.01^{a b}$ \\
\hline Arachidonic & C20:0 & $1.27 \pm 0.01^{b}$ & $1.25 \pm 0.00^{b}$ & $1.24 \pm 0.02^{b}$ & $0.60 \pm 0.03^{a}$ & $1.07 \pm 0.01^{b}$ \\
\hline Behinic & C22:0 & $0.18 \pm 0.01^{c}$ & $0.17 \pm 0.01^{c}$ & $0.15 \pm 0.02^{c}$ & $0.01 \pm 0.01^{a}$ & $0.03 \pm 0.01^{b}$ \\
\hline Lignoceric & C24:0 & $0.14 \pm 0.01^{\mathrm{e}}$ & $0.12 \pm 0.01^{d}$ & $0.07 \pm 0.01^{c}$ & $0.01 \pm 0.01^{a}$ & $0.03 \pm 0.01^{b}$ \\
\hline
\end{tabular}




\subsection{Effect of fermentation on anti- nutrient compositions of $Z$. mauritiana seeds}

The Effect of fermentation on anti-nutrient compositions of $Z$. mauritiana seeds is shoen in table 3. The concentrations of cyanide, tannin and oxalate in all fermented $Z$. mauritiana seed decreases $(p<0.05)$ significantly when compared with the unfermented sample. Saponins content was lowered only in seed fermented for 24 hr. However, the phytate concentration increases in seed fermented for $18 \mathrm{hr}$ when compared with the unfermented sample (Table 3).

\subsection{Effect of fermentation on micro- nutrient compositions of $Z$. mauritiana seeds}

The effect of fermentation on micro-nutrient compositions of $Z$. mauritiana seeds is presented in table 4 . The concentrations of sodium, potassium, calcium, magnesium, copper, manganese, iron zinc and phosphorus in Ziziphus mauritiana seeds significantly $(p<0.05)$ increase with increase fermentation period from $6 \mathrm{hr}$ to $24 \mathrm{hr}$.

\subsection{Effect of fermentation on proximate compositions of $Z$. mauritiana seeds}

The proximate compositions of both fermented and non-fermented Ziziphus mauritiana seeds is presented in table 5 . Moisture contents of the fermented seed increase significantly $(p<0.05)$ while the fibre content decreases with an increase in fermentation period from $6 \mathrm{hr}$ to $24 \mathrm{hr}$. Ash, crude fat, protein and carbohydrate concentration of all fermented samples were not significantly altered $(p>0.05)$ when compared with the unfermented seed

Table 3: Effect of fermentation on anti-nutrient compositions of $Z$. mauritiana seeds

\begin{tabular}{|c|c|c|c|c|c|}
\hline Antinutrient $(\mathrm{mg} / \mathbf{1 0 0 g})$ & Fmt_o hr & Fmt_6 hr & Fmt_12 hr & Fmt_18 hr & Fmt_24 hr \\
\hline Cyanide & $8.54 \pm 0.18^{c}$ & $4.39 \pm 0.16^{b}$ & $3.34 \pm 0.12^{b}$ & $2.80 \pm 0.12^{a}$ & $2.56 \pm 0.06^{a}$ \\
\hline Oxalate & $0.28 \pm 0.00^{d}$ & $0.22 \pm 0.01^{c}$ & $0.19 \pm 0.01^{\mathrm{b}}$ & $0.18 \pm 0.00^{b}$ & $0.14 \pm 0.01^{a}$ \\
\hline Phytate & $0.32 \pm 0.00^{b}$ & $0.27 \pm 0.01^{b}$ & $0.17 \pm 0.01^{a}$ & $0.54 \pm 0.02^{c}$ & $0.37 \pm 0.04^{b}$ \\
\hline Saponins & $55.54 \pm 0.17^{b}$ & $51.63 \pm 0.73^{b}$ & $51.04 \pm 1.03^{b}$ & $50.62 \pm 0.85^{b}$ & $45.95 \pm 1.03^{a}$ \\
\hline Tannins & $90.86 \pm 0.89 c$ & $72.54 \pm 0.10^{b}$ & $43.46 \pm 0.38^{a}$ & $37.49 \pm 0.38^{a}$ & $30.37 \pm 3.06^{a}$ \\
\hline
\end{tabular}

Table 4: Effect of fermentation on micro-nutrient compositions of $Z$. mauritiana seeds

\begin{tabular}{|c|c|c|c|c|c|}
\hline Minerals $(\mathrm{mg} / \mathrm{kg})$ & Fmt_o hr & Fmt_6 hr & Fmt $12 \mathrm{hr}$ & Fmt $18 \mathrm{hr}$ & Fmt $24 \mathrm{hr}$ \\
\hline Sodium & $5.60 \pm 0.20^{a}$ & $9.12 \pm 2.83^{b}$ & $12.61 \pm 2.26^{c}$ & $20.91 \pm 1.41^{\mathrm{d}}$ & $21.41 \pm 1.70^{d}$ \\
\hline Potassium & $21.10 \pm 3.00^{\mathrm{a}}$ & $21.11 \pm 1.55^{\mathrm{a}}$ & $22.00 \pm 4.00^{a}$ & $23.31 \pm 0.14^{\mathrm{a}}$ & $27.61 \pm 1.70^{b}$ \\
\hline Calcium & $8.10 \pm 0.20^{a}$ & $7.90 \pm 0.00^{\mathrm{a}}$ & $8.63 \pm 0.71^{\mathrm{a}}$ & $10.5 \pm 1.01^{b}$ & $11.30 \pm 0.00^{c}$ \\
\hline Magnesium & $12.75 \pm 1.25^{\mathrm{a}}$ & $13.62 \pm 2.26^{a}$ & $17.26 \pm 0.28^{b}$ & $19.05 \pm 0.66^{b}$ & $20.12 \pm 0.82^{b}$ \\
\hline Copper & $2.20 \pm 0.00^{\mathrm{a}}$ & $2.21 \pm 0.57^{a}$ & $2.65 \pm 0.56^{\mathrm{a}}$ & $3.31 \pm 0.14^{b}$ & $3.52 \pm 0.71^{b}$ \\
\hline Manganese & $1.30 \pm 0.20^{\mathrm{a}}$ & $1.30 \pm 0.57^{a}$ & $1.54 \pm 0.42^{\mathrm{a}}$ & $1.62 \pm 0.28^{\mathrm{a}}$ & $2.00 \pm 0.00^{\mathrm{b}}$ \\
\hline Iron & $0.70 \pm 0.30^{\mathrm{a}}$ & $0.70 \pm 0.14^{a}$ & $1.00 \pm 0.00^{\mathrm{b}}$ & $1.04 \pm 0.42^{b}$ & $1.03 \pm 0.28^{b}$ \\
\hline Zinc & $1.20 \pm 0.42^{\mathrm{a}}$ & $1.20 \pm 0.00^{\mathrm{a}}$ & $1.65 \pm 0.56^{a}$ & $1.74 \pm 0.42^{\mathrm{a}}$ & $1.91 \pm 0.14^{\mathrm{a}}$ \\
\hline Phosphorus & $1.10 \pm 0.14^{\mathrm{a}}$ & $1.10 \pm 0.42^{\mathrm{a}}$ & $1.35 \pm 0.56^{a}$ & $1.40 \pm 0.00^{\mathrm{a}}$ & $1.700 .14^{\mathrm{a}}$ \\
\hline
\end{tabular}

Table 5: Effect of fermentation on proximate compositions of $Z$. mauritiana seeds

\begin{tabular}{|l|l|l|l|l|l|}
\hline Proximate (\%) & Fmt_0 hr & Fmt_6 hr & Fmt_12 hr & Fmt_18 hr & Fmt_24 hr \\
\hline Moisture & $4.15 \pm 0.41^{\mathrm{a}}$ & $4.70 \pm 0.10^{\mathrm{a}}$ & $5.59 \pm 0.08^{\mathrm{a}} \mathrm{b}$ & $6.93 \pm 1.41^{\mathrm{b}}$ & $9.98 \pm 1.13^{\mathrm{c}}$ \\
\hline Ash & $3.26 \pm 0.25^{\mathrm{a}}$ & $3.30 \pm 0.10^{\mathrm{a}}$ & $3.31 \pm 0.14^{\mathrm{a}}$ & $3.32 \pm 0.40^{\mathrm{a}}$ & $3.43 \pm 0.34^{\mathrm{a}}$ \\
\hline Fat & $26.46 \pm 0.72 \mathrm{a}$ & $25.33 \pm 0.19^{\mathrm{a}}$ & $25.27 \pm 1.48^{\mathrm{a}}$ & $24.18 \pm 2.62^{\mathrm{a}}$ & $24.26 \pm 2.08^{\mathrm{a}}$ \\
\hline Fiber & $4.93 \pm 0.35^{\mathrm{c}}$ & $4.85 \pm 0.35^{\mathrm{c}}$ & $4.14 \pm 0.50^{\mathrm{b}}$ & $3.34 \pm 0.06^{\mathrm{a}}$ & $3.28 \pm 0.25^{\mathrm{a}}$ \\
\hline Proteins & $41.18 \pm 3.36^{\mathrm{a}}$ & $42.84 \pm 2.08^{\mathrm{a}}$ & $42.88 \pm 1.51^{\mathrm{a}}$ & $44.02 \pm 0.52^{\mathrm{a}}$ & $43.07 \pm 5.47^{\mathrm{a}}$ \\
\hline Carbohydrates & $19.73 \pm 3.22^{\mathrm{a}}$ & $19.00 \pm 2.64^{\mathrm{a}}$ & $19.05 \pm 2.67^{\mathrm{a}}$ & $18.74 \pm 2.12^{\mathrm{a}}$ & $18.01 \pm 5.01^{\mathrm{a}}$ \\
\hline Energy & $478.22 \pm 0.00^{\mathrm{a}}$ & $478.10 \pm 0.00^{\mathrm{a}}$ & $485.70 \pm 0.00^{\mathrm{a}}$ & $490.53 \pm 0.00^{\mathrm{b}}$ & $460.32 \pm 0.00^{\mathrm{a}}$ \\
\hline
\end{tabular}




\subsection{Effect of fermentation on amino acid profiles of $Z$. mauritiana seeds}

The total essential amino acid, conditional amino acid and non-essential amino acid composition of fermented and unfermented $Z$. mauritiana seed are presented in tables 6, 7 and 8 respectively. The total essential amino acids composition of the fermented and nonfermented $Z$. mauritiana seed ranged between $25.02 \pm 0.36 \mathrm{~g} / 100 \mathrm{~g}$ and $34.83 \pm 0.32$ $\mathrm{g} / 100 \mathrm{~g}$. The highest concentration of essential amino acids of the samples was tryptophan $(27.18 \pm 0.08 \mathrm{~g} / 100 \mathrm{~g})$, while the least concentration $(7.43 \pm 0.06 \mathrm{~g} / 100 \mathrm{~g})$ was histidine (Table 6). Fermentation for 12, 18 and $12 \mathrm{hr}$ significantly decreases isoleucine, threonine, phenylalanine and histidine however, leucine, valine, methionine and tryptophan were not altered by fermentation (Table 6).

The total conditional-essential amino acids composition of the fermented and nonfermented $Z$. mauritiana seed ranged between $10.44 \pm 0.10 \mathrm{~g} / 100 \mathrm{~g}$ and $14.20 \pm 0.10$ $\mathrm{g} / 100 \mathrm{~g}$. The highest concentrated conditionally essential amino acids of the samples was arginine $(19.15 \pm 0.25 \mathrm{~g} / 100 \mathrm{~g})$, while the least concentrated $(1.97 \pm 0.01$ $\mathrm{g} / 100 \mathrm{~g}$ ) was cysteine. Conditional amino acids including arginine, cysteine and tyrosine were not altered by fermentation, while, proline and glycine decreases during the fermentation (Table 7).

The total non-essential amino acids composition of the fermented and nonfermented $Z$. mauritiana seed ranged between $21.27 \pm 0.25 \mathrm{~g} / 100 \mathrm{~g}$ and $23.62 \pm 0.23$ $\mathrm{g} / 100 \mathrm{~g}$. The highest concentrated of nonessential amino acids of the samples was glutamic acid $(46.19 \pm 0.23 \mathrm{~g} / 100 \mathrm{~g})$, while the least concentrated $(0.47 \pm 0.09 \mathrm{~g} / 100 \mathrm{~g})$ was ornithine (Table 8). The concentrations of non-essential amino acids including glutamic acid, aspartic acid, alanine were not altered by fermentation, while serine and ornithine decrease during fermentation.

Table 6: Effect of fermentation on the essential amino acid compositions of $Z$. mauritiana seeds

\begin{tabular}{|c|c|c|c|c|c|c|}
\hline Amino Acids & Fmt_0 hr & Fmt_6 hr & Fmt_12 hr & Fmt_18 hr & Fmt_24 hr & Total \\
\hline Lycine & $4.04 \pm 0.02$ & $4.04 \pm 0.08$ & $3.84 \pm 0.02$ & $3.90 \pm 0.03$ & $3.92 \pm 0.01$ & $19.73 \pm 0.07$ \\
\hline leucine & $4.47 \pm 0.02$ & $4.51 \pm 0.04$ & $4.30 \pm 0.05$ & $4.38 \pm 0.01$ & $4.51 \pm 0.02$ & $22.15 \pm 0.14$ \\
\hline Valine & $2.54 \pm 0.02$ & $2.57 \pm 0.04$ & $2.38 \pm 0.01$ & $2.43 \pm 0.02$ & $2.58 \pm 0.01$ & $12.49 \pm 0.06$ \\
\hline isoleucine & $5.76 \pm 0.02$ & $5.72 \pm 0.03$ & $1.73 \pm 0.02$ & $1.78 \pm 0.01$ & $1.87 \pm 0.02$ & $16.85 \pm 0.02$ \\
\hline Threonine & $3.48 \pm 0.02$ & $3.50 \pm 0.02$ & $2.37 \pm 0.03$ & $2.44 \pm 0.02$ & $2.50 \pm 0.02$ & $14.27 \pm 0.1$ \\
\hline phenylalanine & $4.56 \pm 0.02$ & $4.38 \pm 0.23$ & $2.53 \pm 0.02$ & $2.61 \pm 0.03$ & $2.65 \pm 0.02$ & $16.72 \pm 0.23$ \\
\hline methionine & $1.90 \pm 0.04$ & $1.66 \pm 0.02$ & $1.58 \pm 0.01$ & $1.67 \pm 0.01$ & $1.66 \pm 0.02$ & $8.46 \pm 0.03$ \\
\hline Histidine & $2.17 \pm 0.02$ & $1.97 \pm 0.06$ & $1.06 \pm 0.01$ & $1.11 \pm 0.02$ & $1.13 \pm 0.01$ & $7.43 \pm 0.06$ \\
\hline Tryptophan & $5.91 \pm 0.03$ & $5.37 \pm 0.03$ & $5.23 \pm 0.02$ & $5.31 \pm 0.02$ & $5.37 \pm 0.03$ & $27.18 \pm 0.08$ \\
\hline Total & $34.83 \pm 0.32$ & $33.79 \pm 0.32$ & $25.02 \pm 0.36$ & $25.63 \pm 0.37$ & $26.19 \pm 0.33$ & \\
\hline
\end{tabular}

Table 7: Effect of fermentation on the conditional-essential amino acid compositions of $Z$. mauritiana seeds

\begin{tabular}{|l|l|l|l|l|l|l|}
\hline Amino Acids & Fmt_0 hr & Fmt_6 hr & Fmt_12 hr & Fmt_18 hr & Fmt_24 hr & Total \\
\hline Arginine & $3.92 \pm 0.04$ & $3.91 \pm 0.11$ & $3.71 \pm 0.05$ & $3.75 \pm 0.03$ & $3.87 \pm 0.03$ & $19.15 \pm 0.25$ \\
\hline Cysteine & $0.52 \pm 0.01$ & $0.40 \pm 0.02$ & $0.31 \pm 0.03$ & $0.35 \pm 0.01$ & $0.40 \pm 0.02$ & $1.97 \pm 0.01$ \\
\hline Tyrosine & $2.27 \pm 0.01$ & $2.13 \pm 0.03$ & $2.04 \pm 0.01$ & $2.10 \pm 0.02$ & $2.13 \pm 0.03$ & $10.67 \pm 0.08$ \\
\hline Proline & $3.94 \pm 0.03$ & $3.71 \pm 0.04$ & $1.90 \pm 0.03$ & $2.01 \pm 0.04$ & $2.04 \pm 0.01$ & $13.60 \pm 0.06$ \\
\hline Glycine & $3.55 \pm 0.03$ & $3.55 \pm 0.09$ & $2.48 \pm 0.01$ & $2.54 \pm 0.01$ & $2.57 \pm 0.01$ & $14.69 \pm 0.08$ \\
\hline Total & $14.20 \pm 0.10$ & $13.70 \pm 0.12$ & $10.44 \pm 0.10$ & $10.75 \pm 0.11$ & $11.01 \pm 0.10$ & \\
\hline
\end{tabular}

Values are mean \pm SD of 3 determinations. Fmt_0 hr= unfermented sample; Fmt_6 hr= fermented for 6 hr; Fmt_12 $\mathrm{hr}=$ fermented for $12 \mathrm{hr}$; Fmt_18 hr= fermented for 18 hr; Fmt_24 hr= fermented for 24 hr.

Table 8: Effect of fermentation on the non-essential amino acid compositions of $Z$. mauritiana seeds

\begin{tabular}{|c|c|c|c|c|c|c|}
\hline Amino Acids & Fmt_o hr & Fmt_6 hr & Fmt_12 hr & Fmt_18 hr & Fmt_24 hr & Total \\
\hline Glutamic acid & $9.76 \pm 0.02$ & $9.43 \pm 0.15$ & $8.91 \pm 0.03$ & $9.00 \pm 0.04$ & $9.10 \pm 0.01$ & $46.19 \pm 0.23$ \\
\hline Aspartic acid & $7.04 \pm 0.01$ & $7.07 \pm 0.04$ & $6.81 \pm 0.04$ & $6.92 \pm 0.04$ & $7.06 \pm 0.02$ & $34.89 \pm 0.15$ \\
\hline Alanine & $3.02 \pm 0.07$ & $3.04 \pm 0.06$ & $2.87 \pm 0.02$ & $2.92 \pm 0.01$ & $3.07 \pm 0.01$ & $14.91 \pm 0.03$ \\
\hline Serine & $3.69 \pm 0.03$ & $3.65 \pm 0.31$ & $2.61 \pm 0.04$ & $2.70 \pm 0.03$ & $2.74 \pm 0.02$ & $15.38 \pm 0.35$ \\
\hline Ornithine & $0.11 \pm 0.02$ & $0.11 \pm 0.02$ & $0.07 \pm 0.01$ & $0.08 \pm 0.01$ & $0.11 \pm 0.02$ & $0.47 \pm 0.09$ \\
\hline Total & $23.62 \pm 0.23$ & $23.30 \pm 0.21$ & $21.27 \pm 0.25$ & $21.62 \pm 0.25$ & $21.86 \pm 0.19$ & \\
\hline
\end{tabular}




\subsection{Discussion}

The moisture contents of both fermented and unfermented $Z$. mauritiana, fall within the recommended range of $0-13 \%$ as reported by James [23]. These low moisture content will prevent or delay microbial deterioration thus prolong the shelf life of the seed. The increase in the moisture content with an increase in fermentation time was also observed by Okechukwu et al. [24] and Adegbehingbe [25] while fermenting African locust bean, melon seeds and Lima Bean ( $P$. lunatus) seeds respectively. This increase could be attributed to increasing soaking in water as fermentation time increases.

A number of studies have documented increases in crude protein during seed fermentation $[25,26]$, this is, however, contrary to the present study as no fermentation related changes in protein contents of $Z$. mauritiana seeds was observed, this differences could be attributed to the differences in the organism employed in the fermentation. Bacteria fermenting organisms such as Bacillus species are producers of extracellular proteases which could hydrolyze complex proteins in the seed to peptide and amino acids, thus increasing the total nitrogen content [27], this is, however, contrary to the yeast which was used as the fermenting organism in the present study. The reduction observed in crude fibre content was due to the action of cellulolytic micro-organism present in the fermenting substrate [28]

Ash crude fat, protein and carbohydrate concentration of all fermented samples were not significantly altered compared with the unfermented seed. The protein content of $Z$. mauritiana seed reported in this study is higher than 33.64 reported for locust bean [29], $10.77 \pm 0.66 \mathrm{~g} / 100 \mathrm{~g}$ for wheat [30], and $17.37 \%$ for Ugba [28]. This is, however, contrary to report of previous studies [31-33] which reported fermentation related changes in ash, crude fat, protein and carbohydrate contents while studying the effect of fermentation on nutrient and anti-nutrient composition of seed flours. Olusey iet al., [34] also reported that crude fibre, fat and protein contents of $T$. indica seed increases as fermentation progressed, while carbohydrate and ash reduced.
Ash is the measure of mineral content. The concentrations of calcium, sodium, magnesium, manganese, zinc, potassium, phosphorus and copper content of $Z$. mauritiana seeds were appreciably higher than those previously reported for Bambara groundnut [35] soybean [36] and S. stenocarpa seeds [37] and other legumes such as winged bean, cowpea and peanut [38] which suggested that $Z$. mauritiana could be a better source and/or alternative of these minerals. Though, fermentation had no effect on the ash content of $Z$. mauritiana seeds.

The increase in sodium, potassium, calcium, magnesium, copper, manganese, iron zinc and phosphorus concentration with increase fermentation period in $Z$. mauritiana seeds from $6 \mathrm{hr}$ to $24 \mathrm{hr}$ is an indication that these minerals were increasingly released from chelated complex compounds as the activities of fermenting organism increase with time [39]. Animals required these micronutrients for proper body function including eggshell formation, nervous coordination, muscle and heart activities and blood coagulation among many others [24]. Thus fermentation of $Z$. mauritiana seeds will ensure better mineral supply for the production of healthy animals.

Antinutrients including phytate, oxalate, tannins and cyanide are generally toxic and may negatively affect the nutrient value of seeds by hampering protein digestibility and mineral bioavailability [1]. The oxalate and phytate contents of $Z$. mauritiana seed were lower than those reported for tiger nut seed [40]. The levels of saponins in both fermented and non-fermented $Z$. mauritiana seed are within the recommended safe level (below $22.4 \mathrm{mg} / \mathrm{g}$ ) and adequate for exhibiting hypoglycemic, hypolipidemic and antioxidants effects. Tannins have been reported to enhance good health by preventing heart diseases, diarrhoea, cavities and tooth decay in addition to having antimicrobial properties. Therefore, the presence of a low level of tannins would confer some health benefits to the seed.

Oxalates are known for their inhibitory effect on metabolism and the bioavailability of magnesium, calcium, and protein in man. Oxalate also enhanced the formation of kidney stones via the formation of a complex within human subjects [41]. According to Enwere [42] hydrogen cyanide is considered not poisonous, moderately poisonous and 
highly poisonous when concentrations are less than $50 \mathrm{mg} / \mathrm{kg} \mathrm{BW,} 50$ to $100 \mathrm{mg} / \mathrm{kg} \mathrm{BW}$ and over $100 \mathrm{mg} / \mathrm{kg}$ BW respectively. It can be therefore seen that the levels of hydrogen cyanide observed in both fermented and unfermented $Z$. mauritiana seed were far below the levels that can induce any toxic effect when consumed. Furthermore, the reduction in tannin, oxalate and cyanide contents of $Z$. mauritiana seed during fermentation is an added advantage and could be attributed to their solubility in water. This observation correlates with the reports of other researchers on fermented legumes, sorghum, millet, African locust bean, kidney bean and chickpea flours $[1,43-44]$. By implication, the result showed that fermentation had a significant effect in reducing the levels of inherent anti-nutrient factors in $Z$. mauritiana seed.

The digestibility and quality of edible seeds are determined by the type and quantity of unsaturated fatty acids it contains. In the present study, polyunsaturated fats (Linoleic), had the highest concentrations in all the samples obtained. Intake of linoleic acid and linolenic acid are of great medicinal importance for humans; linolenic acid has hypocholesterolemic, anti-inflamatory, immunostimulatory effects and assists in body defence. Linolenic acid on the other hand has been associated with hypoglycemic, antiinflammatory, decrease the risk of cardiovascular diseases.it also aids proper formations of the visual and central nervous, through the formation and regeneration of neurons [45]. It is also noteworthy that the high levels of unsaturated fatty acid than the saturated fat for both fermented and nonfermented $Z$. mauritiana seed will be beneficial in decreasing the plasma LDL cholesterol concentration by increasing the hepatic uptake of LDL particles from the circulation [46]

Although most unsaturated and saturated fatty acids can be synthesized by animal tissues, linoleic series cannot be synthesized and thus must be provided in the diet. If provided in the diet, arachidonic acid can be synthesized from it. This acid, alone or together with linoleic acid, is essential for the maintenance of the normal skin structure [47]. Oleic/linoleic acid ratio (Ole / Lin) has been accepted as a means of assessing edible seed oil quality. The higher the amount of linoleic acid in relation to oleic acid, the better the quality of vegetable oil in avoiding the formation of bad cholesterol. In the present study, the Ole / Lin ratio for both fermented and non-fermented $Z$. mauritiana seed oil was in the range $1 / 3.42$ and 1/3.47, demonstrating the high oil quality.

The observed effect of fermentation on fatty acid contents of $Z$. mauritiana seed is similar to the report of Ijarotimi and Keshinro [29] observed decreases in unsaturated fatty acid and saturated fatty acid composition of African locust bean during fermentation. Achinewhu [48], also observed that fermentation did not have much effect on the fatty acid composition of $P$. macrophylla except for the slight reduction in the total saturated fatty acids. The decreases in the fatty acid composition of $Z$. mauritiana seed was however seen only after 18 and $24 \mathrm{hr}$ of fermentation, this suggests that fermentation of $Z$. mauritiana seed should be done below $18 \mathrm{hr}$ to ensure retention of the fatty acid composition.

With the current emphasis on the consumption of low levels of saturated fats, eliminating trans fatty acid, and increasing intake of poly and monounsaturated fatty acid, the consumption of $Z$. mauritiana seed should be encouraged as it's a good source of beneficial fatty acid for improving the integrity of cardiovascular system thus decreasing the risk of cardiovascular impairment and other nutritional associated disorders.

Previous studies reported that fermentation of oilseed significantly increases EAA content including lysine, histidine, arginine, serine, glycine, alanine, valine, isoleucine, tyrosine and phenylalanine [49]. This is, however, contrary to the loss of isoleucine, threonine, phenylalanine and histidine contents during fermentation of $Z$. mauritiana. This loss could be attributed to the solubility of these amino acids in the fermentation medium. These could be nutritionally detrimental since these EAA cannot be synthesized by animal's tissue. This is, however, not of nutritional concern as arginine and histidine content recorded for both fermented and non-fermented $Z$. mauritiana seed were higher than the arginine $(2.0 \mathrm{mg} /$ day and histidine $(1.9 \mathrm{mg} /$ day $)$ recommended for infants by FAO/WHO [50]. These amino acids play crucial roles in the proper growth and development of infants, thus incorporation of $Z$. mauritiana into infant diet would enhance their growth and 
development particularly in developing countries where animal-based foods are expensive.

The loss of essential, conditional and nonessential amino acids of $Z$. mauritiana seed were however, not evident at fermentation period of below $12 \mathrm{hr}$. Summing up this fact and other findings from this study it is reasonable to assumed that the nutritional quality of $Z$. mauritiana seed is best obtained without fermentation or at fermentation period of below $12 \mathrm{hr}$

\subsection{Conclusion}

Ziziphus mauritiana has high amount of proteins, amino acid, minerals, unsaturated fatty acid and low levels of saturated fatty acid. The seed also contains antinutrient below the recommended safe limit. Fermentation reduced the anti-nutrient levels, some amino acid contents and significantly affect its fatty acid composition. The study suggests that $Z$. mauritiana seed is an alternative protein, unsaturated fatty acid and other nutrient sources. The seed could be employed as alternative source of protein and food supplement for human nutrition. The most plausible and positive effect of the fermentation with high nutrient retention occur $\leq 12 \mathrm{hr}$ of fermentation, thus fermentation of this seed is encouraged below this period.

Competing interests: The authors declare that they have no competing interests

Ethical approval: Not applicable

Acknowledgement: The authors would like to appreciate the technical staff of Chemistry, Biotechnology and Genetic Engineering Laboratory Federal University of Technology, Minna, for their kind assistances.

\section{Author's contributions:}

The work was conducted in collaboration of all authors. Author ARA conducted the study and wrote the manuscript. Authors AYI: supervised the work and revised the manuscript. Authors JCA and MMN co-supervised the work and revised the manuscript. All authors read and approved the final version of the manuscript.

Funding: None

\section{References}

1. Mugendi JBE, Njagi, NM, Kuria, E N, Mwasaru, MA, Mureithi, JG and Apostolides, Z. 2010. Effects of processing technique on the nutritional composition and anti-nutrient content of mucuna bean. Mucuna pruriens L. African Journal of Food Science, 4. 4., pp 156-166

2. Okello, J. 2010. Morphological and nutritional characteristics of Tamarindus indica. Linn. fruits in Uganda http://hdl handlenet/10570/2157 pp 4-16

3. Eromosele IC,Eromosele CO, Kuzhkuzha DM. 1991. Evaluation of mineral elements and ascorbic acid contents in fruits of some wild plants Plant food Hum Nutr 41: 53-57

4. Binita R, Khetarpaul N. 1997. Probiotic fermentation: Effect on antinutrients and digestability of starch and protein of indigenous developed food mixture J Nutr Health, pp 139-147

5. Marina, C. N. A., Theodore N. D., Marina K-C. \& Kouakou, B. (2013). Effect of Fermentation Process on Nutritional Composition and Aflatoxins Concentration of Doklu, a Fermented Maize Based Food. Food and Nut. Sci. 4, 1120-1127

6. Huwale TD. 1985. "Pollen studies in Ziziphus Mauritian cultivars" Ann Aridzone J, 1: 47-50

7. Thanatcha, R, and A Pranee 2011 Extraction and characterization of mucilage in Ziziphus mauritiana Lam Int Food Res J 18:201-212

8. Upadhyay S, Upadhyay P, Ghosh AK, Singh V. 2012. Ziziphus mauritiana: A Review On Pharmacological Potential Of This Underutilized Plant International Journal of Current Research and Review, 4. 3.;141-144

9. Dahiru D, Sini JM and John A. 2006. Africa $L$ Antidiarrhoeal activity of Ziziphus mauritiana root extract in rodents African J Biotechnol, 5 ,10

10. Wadekar RE. 2008. Effect of Ziziphus mauritiana leaf extract on phagocytosis by human neutrophills J Pham. Res.;1. 1.

11. Bhatia A and Mishra T. 2009. Free radical scavenging activity and inhibitory responces of Ziziphus mauritiana seed extract on alcohol induced oxidative An 
international forum for Evidence Based Practices, 1.: 8

12. Mishra T, Kullar N and Bhatia A. 2011. Anticancer potential of Aqueous ethanol seed extract of Ziziphus mauritiana against cancer cell lines and Ehrlich Ascites Carcinoma. Evid. Based Comp. Alt. med., 2011:11

13. Bhatia A and Mishra T, 2010. Hypoglycemic activity of Ziziphus mauritiana aqueous ethanol seed extract in alloxan induced diabetic micePharmaceutical biology 48,604

14. Panchal S, Panchal K, Vyas N, Modi K, Patel V, Bharadia P, Pundarikakshudu K Antiulcer Activity of Methanolic Extract of Zmauritiana stem Bark International Journal of Pharmacognosy and Phytochemical Research,2010 2. 3.: 6-11

15. Abalaka, ME, S Y Daniyan and A Mann M E Abalaka, S Y Daniyan and A Mann. 2010; Evaluation of the antimicrobial activities of two Ziziphus species. ZmauritianaL and Ziziphusspinachristi L. on some microbial pathogens Afr. J Pharm Pharmacol. 4. 4.: 135-139

16. Grice AC. 1996. "Seed production dispersal and germination in cryptostegiagrandio flora and Ziziphus mauritiana invasive shrubs in sub-tropical wood land of Northern Australia" J Ecol, 21. 3.: $324-331$

17. Yerima, B I, and Adamu, H M Proximate chemical analysis of nutritive contents of Jujube. Ziziphus mauritiana. seeds International Journal of the Physical Sciences, 2011;6. 36., pp $8079-8082$

18. AOAC, 2000 Official Methods of Analysis 17th Edn, Association of Official Analytical Chemists, Washington, DC

19. Makkar, HPS, M Blummel, NK Borowy and K Becker, 1993 Gravimetric determination of tannins and their correlations with chemical and protein precipitation methods J Sci Food Agric, 61: 161-165

20. Oboh, G, 2006 Coagulants modulates the hypocholesterotemic effect of tofu. coagulate soy milk. Afr J Biotechnol, 5: 290-294

21. Doss, A, M Pugalenthi, V G Vadivel, G Subhashini, and R ASubash, "Effects of processing technique on the nutritional composition and antinutrients content of under-utilized food legume
Canavaliaensiformis LDC," Inter. Food Res. J., 18, 3, 965-970, 2011

22. Yurchenko S, Sats A, Poikalainan V, Karus A. 2016. Method for determination of fatty acid in bovine colostrum using GC-FID. Food Chem 212: 117-122

23. James CS. 1995. Analytical Chemistry of Foods, Chapman \& Hall, NewYork,NY,USA, 1stedition,1995

24. Okechukwu, RI, NC Emenike, AA Ukaoma, AA. Emejulu, and CO Azuwike 2014"Changes in the Nutrient Composition of the African Oil Bean Meal "Ugba". Pentaclethra macrophylla Benth. subjected to Solid State Natural Fermentation" J Applied Biosci. 51:35913595

25. Adegbehingbe KT. 2013. Microbiological And Nutrient Studies of Fermented Cooked Lima Bean. Phaseolus lunatus. Seeds GJ BAHS, Vol2. 2. 2013:94-101

26. Udensi, EA and Okoronkwo, KA. 2006. Effects of fermentation and germination on the physicochemical properties of Mucuna cochinchinensis protein isolate Afri. J Biotechnol., 5. 10., 896-900

27. Fogarty, WM and Griffin, PJ. 1973. Production and purification of metalloproteases of Bacillus polymyxa. J. Microbiol, 26, pp 191-195

28. Mbah GO, Onyeabo UA, and Udeh BC. 2018. effect of fermentation on nutritional composition of African oil bean seed. Pac J. Sci. Tech. 19(1):244-250.

29. Ijarotimi O.S., Keshinro O.O., 2012. Comparison between the amino acid, fatty acid, mineral and nutritional quality of raw, germi- nated and fermented African locust bean (Parkia biglobosa) flour. Acta Sci. Pol., Technol. Aliment. 11(2), 151165

30. Ijarotimi OS (2012). Influence of germination and fermentation on chemical composition, protein quality and physical properties of wheat flour (Triticum aestivum. J Cer.Oil seeds, 3(3), pp. 35-47

31. Esenwah, CN and Ikenebomeh, MJ. 2008. Processing effects on the nutritional and anti-nutritional contents of African locust bean. Parkia biglobosa Benth. Seed. Pak. J Nut. ,7. 2., pp 214-217

32. Effiong, OO and Umoren, UE. 2011. Effects of multiprocessing techniques on 
the chemical composition of horse eye beans. Mucunaurens. Asian Journal of Animal Sciences,5. 5.: 340-248

33. Osman, MA. 2007. Effect of different processing methods on nutrient composition, antinutritional factors and in vitro protein digestibility of Dolichos lablab bean [Lablab purpuresus. L. Sweet] Pakistan Journal of Nutrition, 6, pp299303

34. Oluseyi EO, Oyesiku TO. 2015. "Chemical and functional properties of fermented, roasted and germinated tamarind. Tamarindus indica. seed flours", Nutrition \& Food Sci. 45, 1, 97-111,

35. Nwokolo, E, 1987. "A nutritional assessment of African yam bean Sphenostylis stenocarpa. Hoechst ex A Rich. Harms and Bambara groundnut. J Sci. Food and Agric. 41, 2, 123-129.

36. Temple, VS, L Odewumi, and K Joseph, "Soybeans and soybean based diets," in Proceedings of the 3rd Regional Workshop on Rural Development, pp 45-50, Jos, Nigeria, August 1991

37. Ndidi UC, Ndidi CU, Olagunju A, Muhammad A, Billy FG, Okpe O Proximate, Antinutrients and Mineral Composition of Raw and Processed. Boiled and Roasted. Sphenostylis stenocarpa Seeds from Southern Kaduna, Northwest Nigeria SRN Nutrition, 2014,

38. Claydon, A. 1975. A review of the nutritional value of the winged bean. Psophocarpus tetragonolobus L. with special reference to Papua, New Guinea," Science New Guinea, 3, 2, 103, 1975

39. Gabriel, RAO and FC Akharaiyi, 2007 Effect of spontaneous fermentation on the chemical composition of thermally treated Jack beans. Canavalia ensiformis. Int J BiolChem, 1: 91-97

40. koye JI, Ene GI. 2018. Effects of Processing on the Nutrient and AntiNutrient Contents of Tiger Nut. Cyperus Esculentus Lativum. J Food Tech Food Chem 1: 101

41. Savita R, Gagan P, Rajesh Y, Deen MK. 2014. Screening of pigeon pea. Cajanuscajan. seeds for study of their flavonoids, total phenolic content and antioxidant properties Int J Pharm Sci Res 28: $90-438$

42. Enwere NJ. 1998. Foods of Plants Origin Afri-Obis Publications Ltd, Nsukka, Nigeria 138-9

43. Elemo GN, Elemo BO, Okafor JNC. 2011. Preparation and nutritional composition of a complementary food formulated from germinated sorghum. Sorghum bicolor. and steamed cowpea. Vignau nguiculata Walp. Am J Food Technol 6: 415-21

44. Onweluzo JC, Nwabugwu CC. 2009. Fermentation of millet. $P$. americanum. and pigeon pea. Cajanuscajan. seeds for flour production Effects of composition and selected functional properties Pak J Nutr 8: 737-44

45. Hirayama, KB, Speridião, PGL, FagundesNeto, U. 2014 Ácidosgraxospoliinsaturados de cadeia longa 2006, v10

46. Helland I, Smith L, Saarem K, Saugstad OD and Drevon CA. 2003. Maternal supplementation with very long-chainn-3 fatty acids during pregnancy and lactation augments children's IQ at 4 years of age Pediatrics111: E39-E44

47. Burton, BJ Nutriçãohumana São Paulo: McGraw-Hill do Brasil, 1979

48. Achinewhu SC. The effect of fermentation on carbohydrate and fatty acid composition of African oil bean seed. Pentaclethra macrophylla. Food Chemistry, 19, Issue 2, 1986, Pages 105116

49. Bujang A, Taib NA. Changes on Amino acids content in Soybean, Garbanzo bean and Groundnut during pre-treatments and tempe making. Sains Malays 2014; 43: 551-7.

50. FAO/WHO, 1991. Protein quality evaluation. Report of Joint FAO/WHO Expert Consultation. FAO Food and Nutrition Paper 51. Rome, Italy, 10-26

Submit your article to AROC JOURNALS -AROC in Pharmaceutical and Biotechnology -AROC in Agriculture

-AROC in Food and Nutrition

-AROC in Natural Product Research

-BIOMED Natural and Applied Science

Via https://arocjournal.com/ 